\title{
MATHEMATICAL MODELING FOR DRYING FIGS IN THIN-LAYER USING MECHANICAL DRYER
}

\author{
M. A. Helmy ${ }^{1}$, H. M. Sorour ${ }^{2}$, M. M. El-Kholy ${ }^{3}$ and H. S. El-Mesery ${ }^{4}$
}

\begin{abstract}
In the present work, selected mathematical thin-layer drying models were fitted to experimental data using non-linear regression analysis techniques. The drying behavior was examined and simulated using four different thin layer drying models (simple, modified simple, logarithmic and two-term exponential model). An empirical equations relating the studied drying parameters with the drying constants of each model were also developed. The analysis was conducted based on the final moisture content (Mf) and the equilibrium moisture content (Me) for calculating the moisture ratio (MR). The results indicated that, both forms of different drying models equations described the drying behavior of whole figs satisfactorily as indicated by the high values of coefficient of determination (R2) and low values of standard error (SE).

The studied drying models were also examined and compared for simulating the drying data obtained from the actual drying of whole figs to select the most applicable model for predicting whole figs moisture content during the drying process using the mechanical dryer

The experimental data used to fit the thin-layer drying of whole figs (Ficus carica). The effect of drying air temperature and velocity on the coefficients of the best suited moisture ratio (MR) model were determined by multiple regression method. In the experimental, the air was passed through the chamber at a variety of air velocity $(0.2,0.4,0.6$ and $1 \mathrm{~m} / \mathrm{s})$, temperature $(55,65,75$ and $85 o C)$ and different of pretreatment of whole figs.
\end{abstract}

According to the results, the reduction rate of figs moisture content was increased with the increasing of drying air temperature and air velocity in all pretreatment of whole figs.

1-Professor of Agric.Eng., Agric. Eng. Dept., Fac. of Agric., Kaferelsheikh Univ. 2- Professor of Agric.Eng., Agric. Eng. Dept., Fac. of Agric., Kaferelsheikh Univ. 3 -Senior Researcher, Agric. Eng. Res. Institute, Agric.Res. Center, Dokki, Giza. 4 -Agric. Eng., Agric. Eng. Res. Institute, Agric. Res. Center, Dokki, Giza. 
The logarithmic model equation could be considered the most proper model for describing the drying behavior of whole figs and predicting the change in moisture content. The value of (Me) for all drying models, substituting in calculating the moisture ratio showed better prediction of moisture content in comparison with value of (Mf) for all pretreatment of whole figs.

\section{INTRODUCTION}

he drying of agricultural products, common method of natural
preservation by reducing the moisture content, has always been a
sign cant contribution to the income of the agricultural societies. Figs, one of the earliest cultivated fruits, with several varieties dried and stored for later consumption (Vinson, 1999).

Goyal et al., (2007) studied the drying kinetics of plum (control, blanching and blanching in $1 \%$ solution as pretreatments) in a tunnel dryer at 55,60 and $65^{\circ} \mathrm{C}$ air temperatures. Drying of plum slices occurred in the falling rate period. It was found that treated plum slices dried faster. Six thin layer drying models were fitted to the experimental moisture ratio data. Among the mathematical models investigated, the logarithmic model satisfactorily described the drying behaviour of plum slices with high (R2) values.

Doymaz and Pala, (2002) studied the applicability of several forms of thin layer drying equations to drying grape. The experiments were preceded using a convective dryer in single layer with air at $60^{\circ} \mathrm{C}$. Grapes were surface treated by different dipping solution on hot air drying. The drying rate of grapes was modeled by the page and exponential equations. They found that the values of $\mathrm{R}$ obtained from the page equation are higher than those attained from the exponential equation. The $\mathrm{R}$ values of the page equation vary between 0.995 and 0.999 , and between 0.973 and 0.995 for the exponential equation. Both equations could represent the correlation between the moisture and drying time.

Inci and Dursun, (2003) investigated the drying behavior of single apricots, hanging in the flow direction of hot air in a drying chamber. In the experiments, the air was passed through the chamber at a variety of flow rates $(0.2,0.5,1.0$ and $1.5 \mathrm{~m} / \mathrm{s})$ and temperatures $(50,60,70$ and 80 oC). In order to obtain drying data, the changes in the mass and inner 
temperatures of the apricots were recorded as well as the drying air properties. The variations of drying rates with time and moisture content were used to test fourteen different one-layer drying models given in the literature and a new model was developed. Among all the models, the logarithmic model was found to be the best for explaining the drying behavior of apricots. The effects of drying air flow rates and temperatures on the constants and coefficients of the models were also studied by multiple regression analysis. It was found that the logarithmic model could represent single apricot drying kinetics within $99.9 \%$ accuracy.

The main objective of the present study was to examine and compare the applicability of four different thin layer drying models (simple, modified simple, logarithmic and two-term exponential model) on simulating and predicting the change in whole figs moisture content during the drying process using the proposed dryer and determine final quality of the dried whole figs.

\section{MATERIAL AND METHODS}

The experimental were carried out using fresh whole figs "Ficus Carica" its local name is "Sultani". Whole fig fruits were treated before drying by treatment (A):- the fruits sulfured by dipped in $1.5 \%$ Sodium Metabisulfit for two minutes and treatment (B):- The fruits were dipped in $1 \%$ sodium hydroxide to crack the skins at $90{ }^{\circ} \mathrm{C}$ for one minute before treated with solution of $1.5 \%$ Sodium Metabisulfit for two minutes. Four levels of drying air temperature $\left(55-65-75\right.$ and $\left.85{ }^{\circ} \mathrm{C}\right)$ and four levels drying air velocity (0.2 - $0.4-0.6$ and $1 \mathrm{~m} / \mathrm{s})$ the approach led to used a small scale industrial figs dryer using butane-gas as heat energy source and also describe and predict the change in fig moisture content during actual drying process using the proposed dryer.

\section{Mathematical modeling of drying curves and fitting methods}

An application of most convenient drying model describing the drying behavior of whole figs, four different drying models shown in Table (1) were examined for fitting the drying data. The moisture ratio usually expressed as $\left(\mathrm{M}-\mathrm{M}_{\mathrm{o}}\right) /\left(\mathrm{M}_{\mathrm{o}}-\mathrm{M}_{\mathrm{e}}\right)$ or $\left(\mathrm{M}-\mathrm{M}_{\mathrm{o}}\right) /\left(\mathrm{M}_{\mathrm{o}}-\mathrm{M}_{\mathrm{f}}\right)$. 
Table (1): The mathematical models used for describing the drying data.

\begin{tabular}{|l|l|l|}
\hline Model & Equation & References \\
\hline The simple exponential & $M R=\exp (-K t)$ & Lewis, 1921 \\
\hline The modified simple & $M R=A \cdot \exp (-K t)$ & $\begin{array}{l}\text { Henderson } \& \\
\text { Pabis, 1961 }\end{array}$ \\
\hline The logarithmic & $M R=A \cdot \exp (-K t)+C$ & yagcioglu, 1999 \\
\hline $\begin{array}{l}\text { The two-term } \\
\text { exponential }\end{array}$ & $M R=a \cdot \exp \left(-K_{o} t\right)+$ b.exp $\left(-K_{I} t\right)$ & Glenn, 1978 \\
\hline
\end{tabular}

Where:

$\mathrm{MR}=$ moisture ratio, dimension less

$\mathrm{M}=$ material moisture content, $(\mathrm{d} \mathrm{b}), \mathrm{kg}$ water $/ \mathrm{kg}$ dry solid.

$\mathrm{M}_{\mathrm{e}}=$ equilibrium moisture content of fruits with the drying air, \%

$\mathrm{t}=$ time, $\mathrm{h}$.

$\mathrm{k}=$ the drying rate constant, $\mathrm{h}^{-1}$

A, $\mathrm{C}, \mathrm{a}, \mathrm{b}=$ experimental constant, dimension less

The analysis was conducted based on the final moisture content (Mf) and the equilibrium moisture content (Me) for calculating the moisture ratio (MR).

\section{Moisture content of figs:}

The initial moisture content on dry basis, "Mdo" of the fresh fruits was determined by the vacuum oven drying method. Samples of the fruit mass "Wo" were dried in a vacuum oven at $70{ }^{\circ} \mathrm{C}$ until the mass "Wd" of the dried sample became stable, according to (A.O.A.C, 1985).

The instantaneous moisture content on dry basis, "Mt" at any time can be calculated from the following equation as mentioned by (El-Sebaii et al., 2002):

$$
M_{t}=\left[\frac{\left(M_{o}+1\right) \times W_{t}}{W_{o}}\right]-1
$$

Where:

$\mathrm{Wo}=$ mass of the original fresh fruits, $\mathrm{kg}$.

$\mathrm{Wt}=$ mass of dried to dried at any time, $\mathrm{kg}$.

\section{Mass of fruits.}

The mass of figs samples was measured using an electrical digital balance model D-type with a maximum capacity of $3000 \mathrm{~g}$ and measured to an accuracy of $0.01 \mathrm{~g}$. 


\section{Rehydration ratio.}

Rehydration ratio was used to express ability of the dried material to absorb water (Lewicki, 1998). It was determined by the following equation:

Rehydration ratio $=\frac{\text { Mass of water absorbed during rehydration }}{\text { Mass of water removed during drying }}$

\section{Reducing sugar (g/100g on dry weight basis).}

It was determined by the method described in (A.O.A.C, 1985).

\section{RESULTS AND DISCUSSION}

\section{Effect of different drying parameters on moisture ratio of figs}

The moisture ratio against time, curves for thin layer drying of whole figs are shown in figure (1). The effect of increasing the air temperature on drying rate, when air velocity was constant, is evident. After an initial short period which practically coincides with the heating up period, the drying rate reaches a maximum value and then the product dries following a falling drying rate. The period of constant drying rate came out to be either very small or not to exist at all, for all the combinations of the parameters tested, a typical behavior for fruits. This shows that diffusion is dominant physical mechanism governing moisture movement in the figs. The value of moisture ratio decreased rapidly, with consequent increase of the drying rate, when air temperature increased. These results are in agreement with those reported by (Babalis and Belessiotis, 2004).

\section{Effect of Different Dehydration Methods on Quality of Dried Fig.}

Regarding to rehydration process results revealed that the lower rehydration ratio was observed with treatment (A) while, the higher value was recoded with treatment (B) for all dehydration methods. On the other hand, higher drying air temperature and air velocity produced lower finial moisture content of the dried figs and also higher skin permeability which increase the water absorbability of the dried figs. Sugars, among several components are considered to be the most important in determining the quality fruits. The initial concentration of reducing sugar for fig was $67.55 \%$. The high damage of reducing sugar was done by pretreatment (B), while the low damage was done by pretreatment (A). 


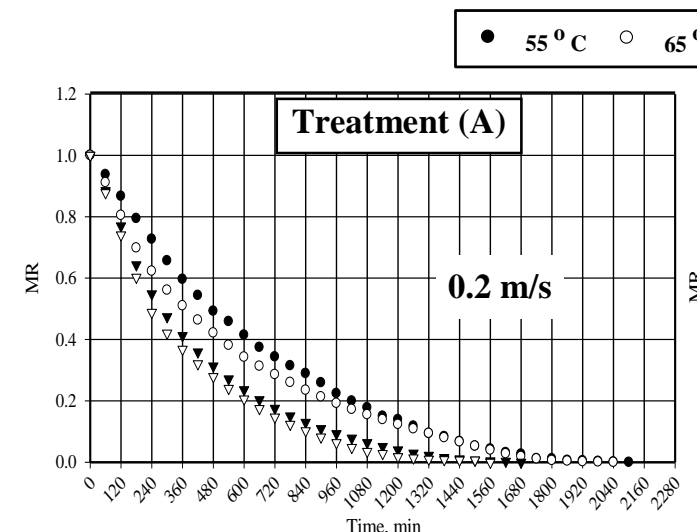

$$
65^{\circ} \mathrm{C} \quad \nabla \quad 75^{\circ} \mathrm{C} \quad \nabla \quad 85^{\circ} \mathrm{C}
$$
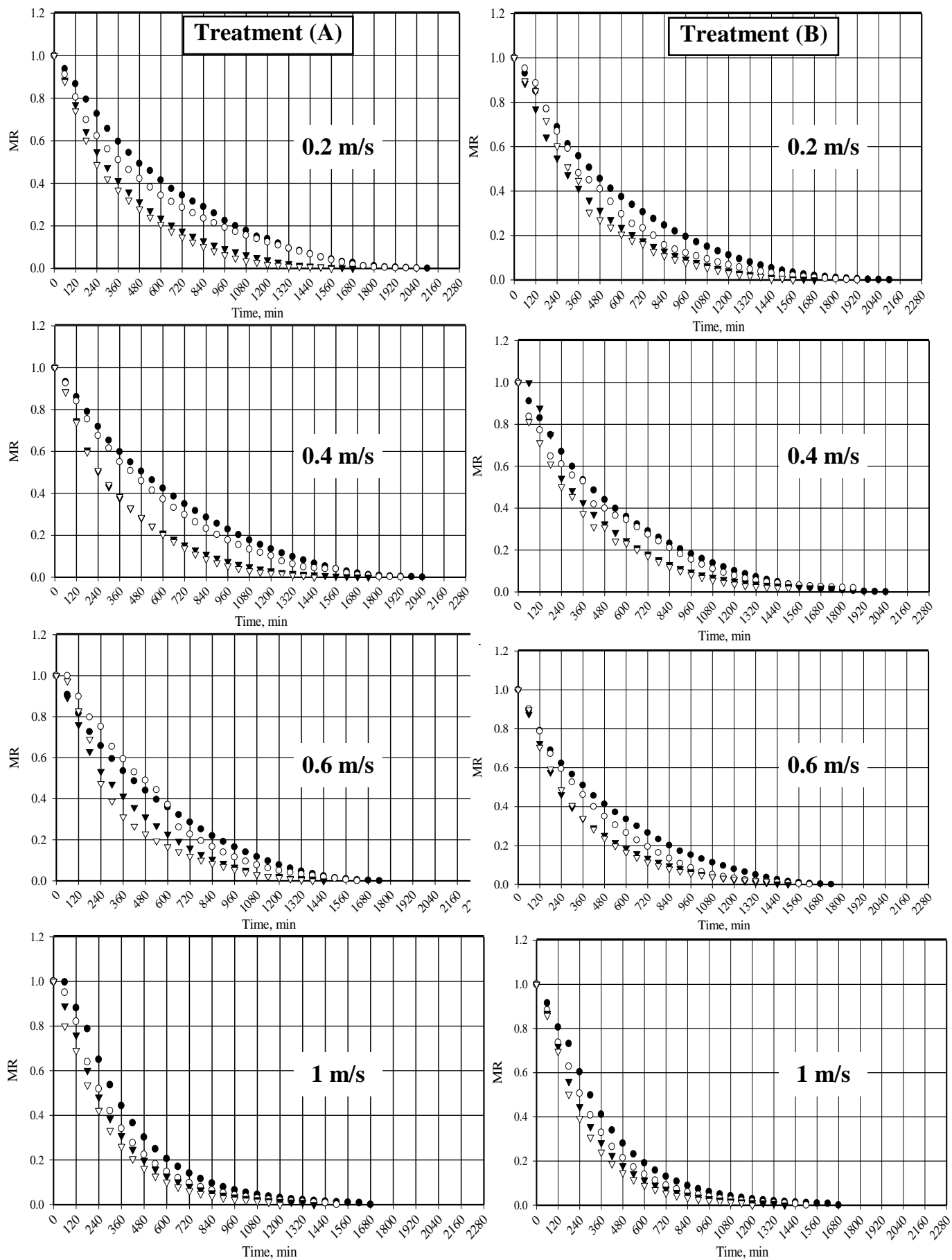

Fig. (1): Effect of different air temperature and air velocity on moisture ratio of figs at different pretreatment of figs.

The $17^{\text {th }}$. Annual Conference of the Misr Society of Ag. Eng., 28 October, $2010 \quad-1874-$ 


\section{A Comparison Evaluation for Different Studied Drying Models.}

The change in moisture content with time was affected by the studied drying parameters and the drying constants for all different drying models.

A comparison study for the four different drying models (simple, modified simple, logarithmic and two term exponential) was conducted to assess the most proper drying model for simulating and describing the drying behavior of figs under different levels of drying air temperature, air velocity and two pretreatment of whole figs.

The results indicated that, the drying behavior of whole figs satisfactorily as indicated by the high values of coefficient of determination $\left(\mathrm{R}^{2}\right)$ and low values of standard error (SE). All the studied models could describe the drying behavior of figs satisfactory as indicated from the higher correlation coefficients for all models. On the other hands, the logarithmic model equation could be considered the most proper model for describing the drying behavior of figs and predicting the change in moisture content.

Figure (2) illustrate the measured and predicted values of moisture content for different drying models at different levels drying air temperature, $1 \mathrm{~m} / \mathrm{s}$ drying air velocity, two levels pretreatment of figs.

\section{CONCLUSION}

The obtained results could be summarized as follow:

1.The results assured that, the reduction rate of figs moisture content was increased with the increasing of drying air temperature and air velocity in all pretreatment of whole figs. On the other hand, the fig moisture content reduction rates on the treatment $(B)$ were higher than that in treatment $(\mathrm{A})$ for all the combination of the parameters.

2. The results showed that, both the final moisture content (Mf) and equilibrium moisture content (Me) were decreased with increasing of drying air temperature and air velocity. The value of $(\mathrm{Me})$ for all drying models, substituting in calculating the moisture ratio showed better prediction of moisture content in comparison with value of (Mf) for all pretreatment of whole figs. 


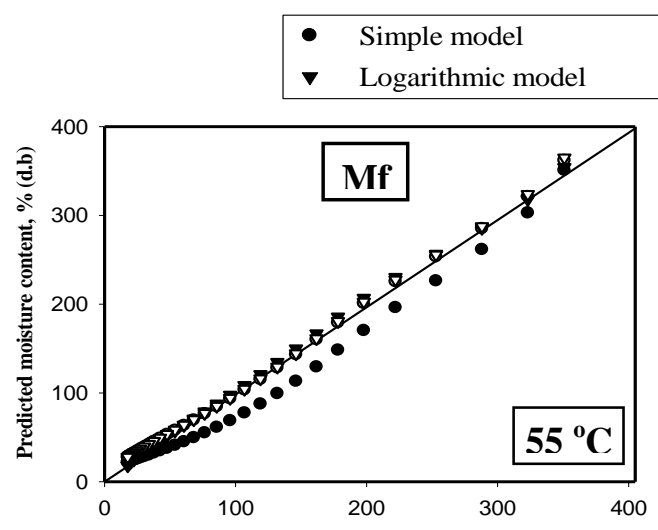

O Modified simple model

$\nabla \quad$ Tow - term exponential
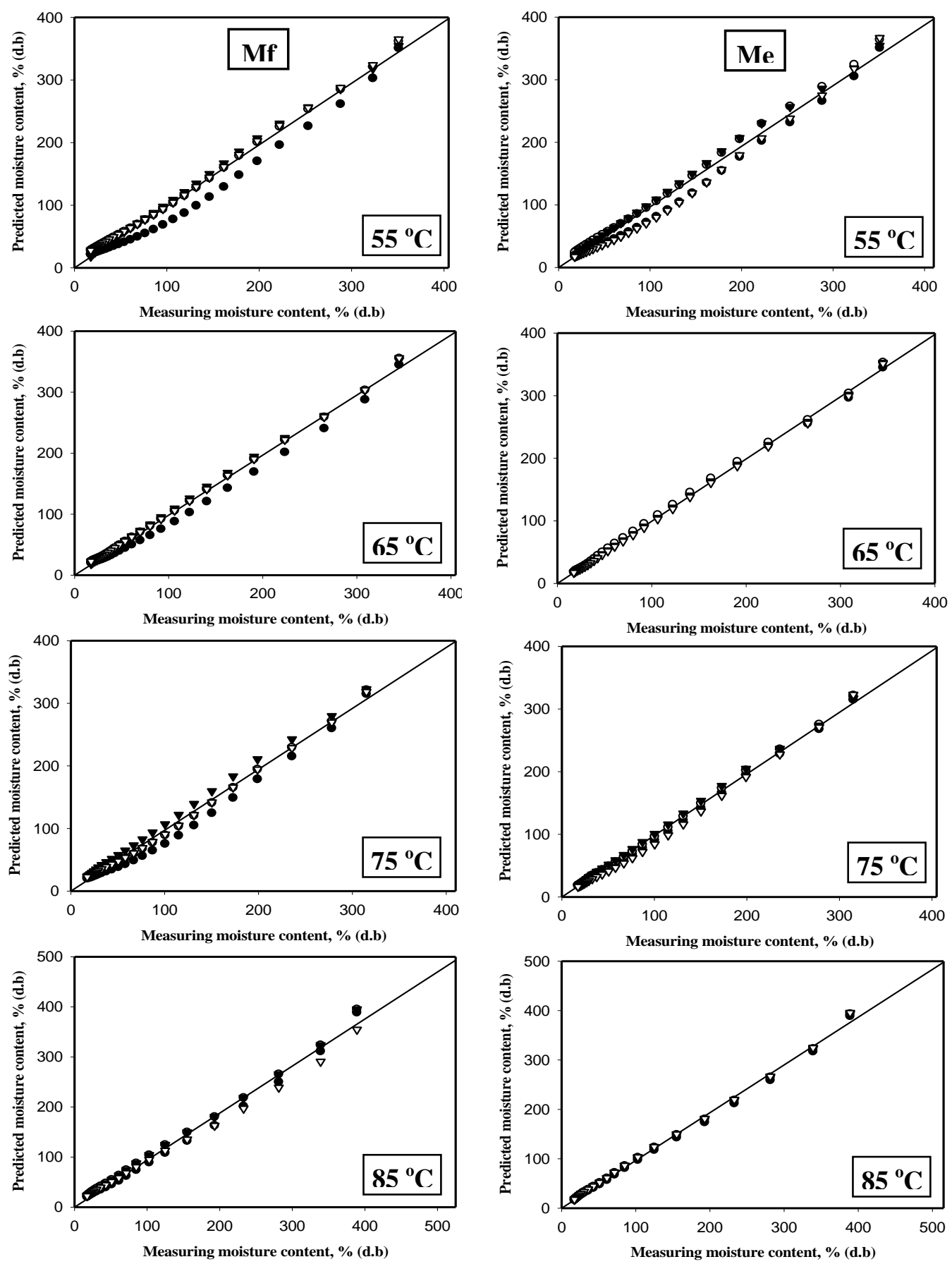

Figure (2): Measured and predicted values of figs moisture content for different models at different drying air temperature with drying air velocity $1 \mathrm{~m} / \mathrm{s}$.

The $17^{\text {th }}$. Annual Conference of the Misr Society of Ag. Eng., 28 October, $2010 \quad-1876$ - 
3. The results showed that, the logarithmic model equation could be considered the most proper model for describing the drying behavior of figs and predicting the change in moisture content. The value of $(\mathrm{Me})$ for all drying models, substituting in calculating the moisture ratio showed better prediction of moisture content in comparison with value of (Mf) for all pretreatment of simple figs.

$$
M R=0.997 \times \exp (-0.003 \times t)+0.0134
$$

\section{REFERENCES}

A.O.A.C. (1985). Official Methods of Analysis, association of official analytical chemists Washington, D.C. USA.

Babalis, S. J. and V. G. Belessiotis (2004). Influence of the drying conditions on the drying constants and moisture diffusivity during thin-layer drying of figs. Journal of food Engineering 65(3): 449458.

Doymaz. I. and M. Pala (2002). The effect of dipping pretreatment on air drying rates of the seedless grapes. Journal of food Engineering, 52, 413-417.

El-Sebaii A. A, S. Aboul-Enien, M. R. I, Ramadan, and H. G., ElGohary, (2002). Parametric study of a solar air heater with and without thermal storage for solar drying applications. Renewable Energy;21:505-22.

Glenn, T. L. (1978). Dynamic analysis of grain drying system, Unpublished PhD. Thesis, Ohio State University, Ann Arbor, MI.

Goyal, R. K., A. R. P. Kingsly, and M. R. Manikantan, (2007). Mathematical modelling of thin layer drying kinetics of plum in a tunnel dryer . Journal of Food Engineering, 40, 219-226.

Henderson, S. M. and S. Pains (1961). Grain drying theory. 1: temperature effect on drying coefficient. J. Agric. Eng. Res. 6 (3): 169.

Inci, T. T., and P. Dursun, (2003). Modelling of drying kinetics of single apricot. Journal of Food Process Engineering, 58, 23-32.

Lewicki, P. P (1998). Some remarks on rehydration of drird foods. Journal of Food Process Engineering, 36, 81-87.

Lewis, W. K. (1921). The rate of drying of solid materials. J. of Ind. Eng. Chem. 13(5):427- 432. 
Vinson, J. A. (1999). The functional food properties of figs. Cereal Foods World, 44(2), 82-87

Yagcioglu, A. (1999). Drying techniques of agricultural products. Ege. Univ., Faculty of Agriculture, Publication No:536 Bornova, Izmir, Turey (in Turkish).

\section{الملخص العربي \\ نموزج رياضى لتجفيف التين فى طبقة رقيقة بأستخدام مجفف ميكانيكى لئن}

ممدوح عباس حلمى' - حسين محمد سرور ' - محمد مصطفى الخولى ' - هانى سراج المسيرى ؛ تم تطوير وتصنيع مجفف ميكانيكي يعمل بغاز البتوجاز كمصدر للطاقة الحراريـة لتجفيف ثمـار

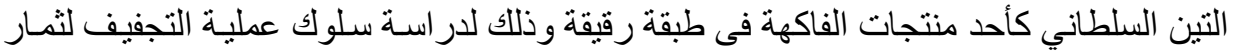

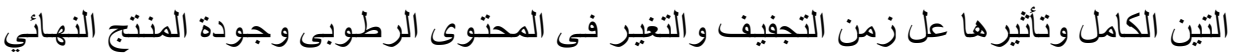

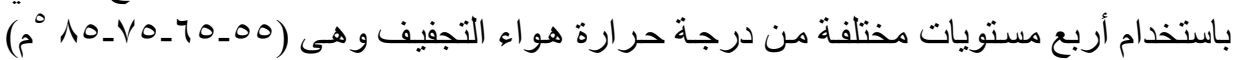

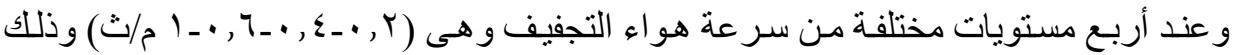
بمعاملة ثمار التين السلطاني بمعاملات أولية مختلفة قبل عملية التجفيف ومنها:

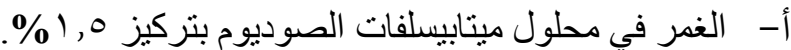

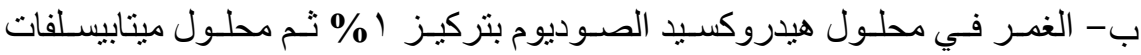

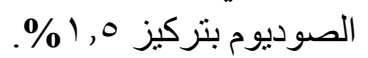

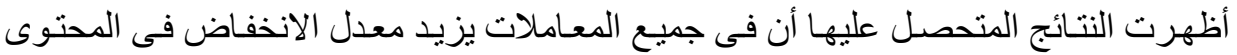

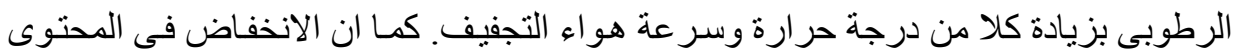

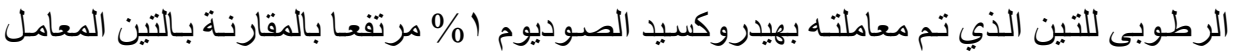

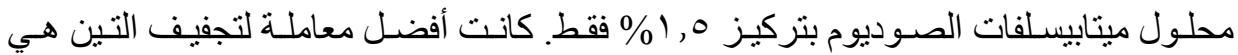

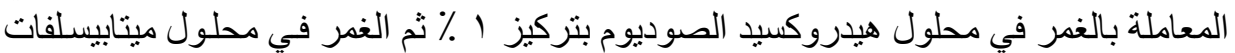

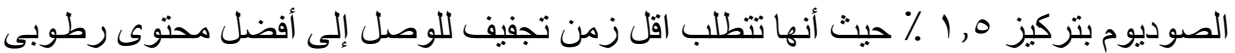
متوازن و امن للتخزين.

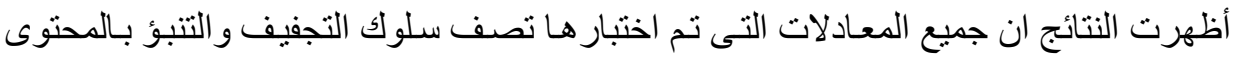

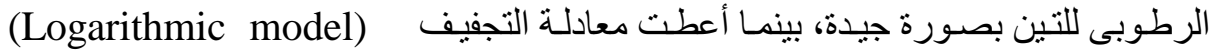

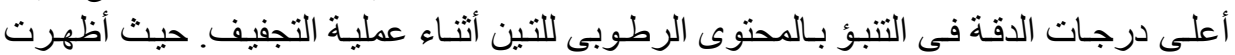

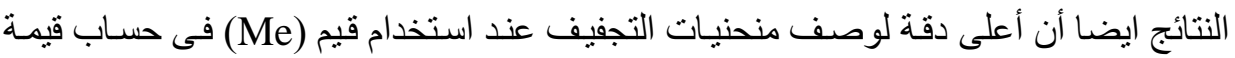
MR $=0.997 \times \exp (-0.003 \times t)+0.0134$

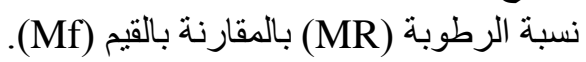

1 - أستاذ الهندسة الزر اعية ـ قسم الهندسة الزر اعيةـ كلية الزر اعةـ جامعة كفر الثيخ.

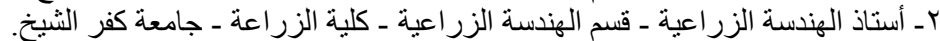

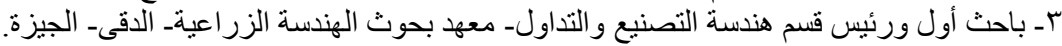

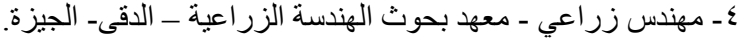

